\title{
Pola Permukiman Tepian Air Studi Kasus : Desa Sepuk Laut, Punggur Besar dan Tanjung Saleh Kecamatan Sungai Kakap, Kabupaten Kubu Raya
}

\author{
Jawas Dwijo Putro, M. Nurhamsyah \\ Program Studi Arsitektur, Fakultas Teknik, Universitas Tanjungpura, Indonesia \\ Jawas_d_putro@yahoo.com, nurhamsyahmuhammad@gmail.com
}

\begin{abstract}
ABSTRAK
Proses terbentuknya lingkungan permukiman dimungkinkan karena adanya proses penciptaan lingkungan hunian sebagai wadah fungsional yang menampung segala kebutuhan manusia dan dilandasi oleh pola aktifitas serta merupakan hasil interaksi antara manusia atau kelompok masyarakat dengan setting (rona lingkungan) baik bersifat fisik maupun non fisik (sosial budaya). Manusia dalam menempati lingkungan huniannya disesuaikan dengan preferensi lingkungan yang menyangkut pemahaman karakteristik alam dan manusia serta hubungan timbal baliknya. Penyesuaian ini memunculkan konsep bermukim yang memperlihatkan cara masyarakat beradaptasi dengan lingkungan dan membentuk pola permukiman. Seperti halnya yang dibahas dalam penelitian ini dengan mengambil kasus masyarakat di tiga desa yaitu ; Desa Sepuk Laut, Desa Tanjung Saleh, dan Desa Punggur Besar Kecamatan Sungai Kakap Kabupaten Kubu Raya, yang beradaptasi dengan lingkungan dan membentuk pola pemukiman pada kawasan tepian air. Hasil penelitian ini memperlihatkan bahwa pola permukiman yang terbentuk pada tiga desa diatas mengacu pada tahapan perkembangan kawasan pinggiran sungai atau air, struktur pola permukiman kawasan yang linier, orientasi kearah tepian air, kepadatan dan kualitas bangunan, serta topografi tepian air.
\end{abstract}

Kata kunci: pola Permukiman, tepian Air

\begin{abstract}
The process of settlements formation was possibly made by the process of creating dwelling environment as a functional space that accommodate all human needs, These condition are based on the patterns of activity and interaction between people or society with the their environmen setting; both physical and non-physical (social and cultural). In occupied their environment, humans are adapt to the environment preferences concerning their understanding to the natural characteristics and vice-versa. This adaptation led to the concept of living that shows how people adapt to the environment and creating their settlement patterns. This study used case study from three villages, namely; Sepuk Laut village, Tanjung Saleh village, and Punggur Besar village of Sungai Kakap Sub-district, Kubu Raya Regency, which adapt to the environment and form a pattern of settlement in the waterfront areas. The results of this study shown that the settlement pattern formed based on the stage of development of the river and waterfront areas. Besides, it also found that the structure of the settlement is in linear patterns, orientation to the water, the density and quality of the buildings, and the topography of the waterfront.
\end{abstract}

Keywords: settlement patterns, waterfront

\section{Pendahuluan}

Setiap manusia secara mendasar mempunyai preferensi dalam memilih tempat tinggal. Kedekatan dengan fasilitas penunjang kebutuhan sehari-hari dan kemudahan akses menjadi pilihan dalam memilih tempat tinggal. Pertumbuhan kota dengan fasilitas pendukungnya menjadi magnet bagi setiap orang untuk memilih tempat tinggal yang berdekatan dengan pusat kota. Keinginan setiap orang untuk mendekatkan tempat tinggal dengan pusat 
kota mengakibatkan keterbatasan lahan untuk bermukim di perkotaan. Akibatnya biaya yang dibutuhkan untuk bermukim di kota semakin mahal sehingga hanya orang-orang yang berpenghasilan tinggi yang dapat tinggal di perkotaan.

Menurut Turner (1976), mereka yang berpendapatan tinggi yang telah mempertimbangkan lingkungan sekitar sebagai salah satu atribut penentu pilihan, sedangkan mereka yang berpendapatan rendah masih berusaha mencari jalan guna mendapatkan tempat bermukim. Walaupun prioritas kelompok berpendapatan rendah adalah mendapatkan tempat bermukim, namun faktor lokasi juga amat penting. Pertimbangan lokasi adalah kemudahan untuk mencapai tempat kerja dan menyatu dengan komunitas sekitar. Selain itu, pertimbangan lainnya adalah kemudahan untuk berhubungan dengan tempat-tempat lain.

Hunian bagi sebagian orang tidak hanya sebagai tempat bermukim saja, tetapi dapat berfungsi luas seperti sebagai tempat bekerja, belajar, berkumpul, bersosialisasi dan kegiatan-kegiatan yang mendukung keberlangsungan hidup. Setiap orang mempunyai keinginan hunian yang mereka tempati dapat fungsional mewadahi setiap aktivitas sehari-hari. Menurut Snyder (1985), terbentuknya lingkungan permukiman dimungkinkan karena adanya proses pembentukan hunian sebagai wadah fungsional yang dilandasi oleh pola aktifitas manusia serta pengaruh setting (rona lingkungan) baik yang bersifat fisik maupun non fisik (sosialbudaya) yang secara langsung mempengaruhi pola kegiatan dan proses perwadahannya.

Menurut Amos Rapoport (1977:81) bahwa orang akan menyesuaikan dengan preferensi yang dimilikinya untuk memilih lingkungan hunian. Pemilihan hunian disesuaikan dengan preferensi lingkungan yang melibatkan pemahaman karakteristik orang dan lingkungannya. Pilihan yang ada, baik lingkungan fisik maupun lingkungan sosial, atau alasan ekonomi dan alasan lainnya hanya diterapkan bila individu tersebut punya kesempatan memilih, jika tidak mempunyai kesempatan, maka timbullah masalah-masalah lingkungan. Ketika lingkungan yang diinginkan tidak dapat dipilih, kehidupan orang akan terpengaruhi dari cara mereka beradaptasi, Langkau Betang: Vol. 2, No.1 (ISSN 2355-2484) mengurangi ketidakcocokan, dan melakukan aktivitas tertentu yang sangat sulit.

Preferensi konsep bermukim bagi masyarakat berpenghasilan rendah pertimbangannya tidak hanya dekat dengan kota tetapi bagaimana mereka dapat beradaptasi dengan lingkungan hunian. Mereka biasa menyesuaikan dengan lingkungan yang padat di perkotaan dan juga lingkungan baru seperti di hutan, pinggiran sungai, atau pulaupulau yang awalnya tidak berpenghuni.

Konsep bermukim ini menjadi sangat menarik jika dilihat bagaimana mereka dapat beradaptasi terhadap lingkungan yang sebelumnya belum ada penghuninya dan juga fasilitas serta akses belum ada. Konsep bermukim ini masih ada dan dapat ditemui di beberapa daerah salah satunya di desa Sepuk Laut, Tanjung Saleh dan Punggur Besar Kecamatan Sungai Kakap Kabupaten Kubu Raya. Ketiga desa ini terletak cukup jauh dari ibu kota kecamatan dan untuk mengaksesnya hanya dapat lewat jalur air (sungai dan laut). Permukiman di ketiga desa ini berada ditepian air.

\section{Tujuan dan Manfaat Penelitian}

Tujuan dari penelitian ini adalah untuk menemukan karakteristik pola permukiman tepian air dan unsur pembentuk lingkungan permukiman tersebut. Penelitian ini diharapkan dapat memberikan manfaat teoritis dan empiris. Manfaat teoritis dari penelitian ini adalah menemukan pola permukiman tepian air dan unsur pembentuk lingkungannya serta memperkaya teori tentang pola permukiman tepian air. Sedangkan manfaat empiris dari penelitian ini adalah menghasilkan pedoman dan acuan dalam perancangan kawasan permukiman tepian air yang sesuai dengan karakteristik lingkungan tersebut.

\section{Tinjauan Pustaka}

\subsection{Pola Permukiman}

Pola adalah gambar yang dipakai untuk contoh, corak, sistem, bentuk yang tetap, kombinasi sifat kecenderungan yang khas, informasi bentuk pengorganisasian, teknik penyusunan, pedoman, kerangka, cara dan usaha. (Depdikbud, 1988). Menurut Rapoport (1989), pola adalah alat untuk mengenali suatu fenomena. pola 
permukiman merupakan segala sesuatu yang berfungsi sebagai pedoman untuk menjelaskan dalam menggambarkan suatu kondisi permukiman dengan menggunakan unsur-unsur dari permukiman itu sendiri.

Menurut Rapoport (1989:94-95), klasifikasi pola permukiman secara garis besar dapat dikenali melalui 4 (empat) klasifikasi, yaitu:

a. Batas (boundaries) merupakan batas daerah kekuasaan suatu wilayah atau sebuah permukiman yang dibuat oleh masyarakat setempat, baik dalam bentuk fisik maupun non fisik;

b. Jenis fasilitas (massa), yaitu pengelompokan elemen fisik dalam suatu permukiman yang merupakan tempat melakukan aktivitas sekaligus sebagai fasilitas bagi penghuni dan penggunanya. Fasilitas permukiman ini dapat berbentuk fasilitas umum (fasum) dan fasilitas sosial (fasos);

c. Tata ruang (zona) merupakan pembagian daerah kegiatan penghuni dalam suatu permukiman, yang diatur berdasarkan struktur keyakinan, aturanaturan adat atau kebiasaan masyarakat setempat;

d. Ragam hias, yaitu unsur-unsur dominan yang banyak ditemukan pada permukiman, baik alami maupun buatan manusia (craftmanship). Ragam hias juga ada yang memiliki latar belakang kebudayaan yang berhubungan dengan kepercayaan masyarakat adat setempat, ada juga yang tidak.

Abdullah (2000), juga membedakan pola permukiman secara garis besar menjadi 2 tipe yaitu; pola permukiman yaitu :

a. Mengumpul (compact settlement), pola ini dapat berbentuk radial, linier, dan papan catur

b. Menyebar (scattered, dispersed), pola ini dapat berbentuk multi pusat dan tersebar murni

Menurut Taylor (1980) Pola permukiman terdiri dari:

a. Sub Kelompok Komunitas (Cluster) yaitu pola permukiman tipe ini berbentuk cluster, terdiri dari beberapa unit atau kelompok unit hunian, memusat pada ruang-ruang penting.

b. Face to face yaitu pola permukiman tipe ini berbentuk linier, antara unit-unit hunian sepanjang permukiman dan secara linier terdapat perletakan pusat.

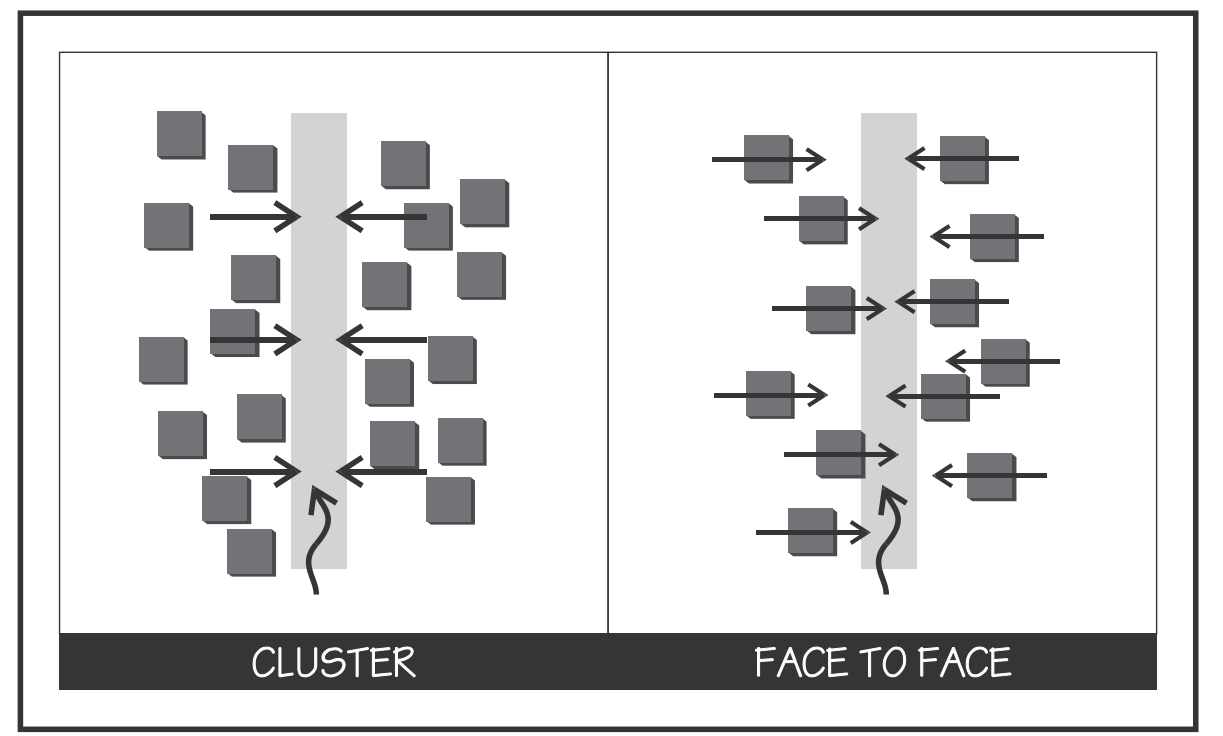

Gambar 1: Pola Permukiman

Sumber: Taylor, 1980

Menurut Taylor (1980) Struktur Ruang Permukiman dikelompokan menjadi:

a. Linier, yaitu suatu pola sederhana dengan peletakan unit-unit permukiman (rumah, fasum, fasos dan sebagainya) secara terus menerus pada tepi sungai dan jalan. Pada pola ini kepadatan tinggi, dan kecenderungan ekspansi permukiman dan mixed use function penggunaan lahan beragam.

b. Cluster, pola ini berkembang dengan adanya kebutuhan lahan dan 
penyebaran unit-unit permukiman telah mulai timbul. Kecenderungan pola ini mengarah pada pengelompokkan unit permukiman terhadap suatu yang dianggap memiliki nilai "penting" atau pengikat kelompok seperti ruang terbuka komunal dalam melakukan aktivitas bersama. c. Kombinasi, yaitu kombinasi antara kedua pola di atas menunjukkan bahwa selain ada pertumbuhan juga menggambarkan adanya ekspansi ruang untuk kepentingan lain (pengembangan usaha dan sebagainya). Pola ini menunjukkan adanya gradasi dari intensitas lahan dan hirarki ruang mikro secara umum.

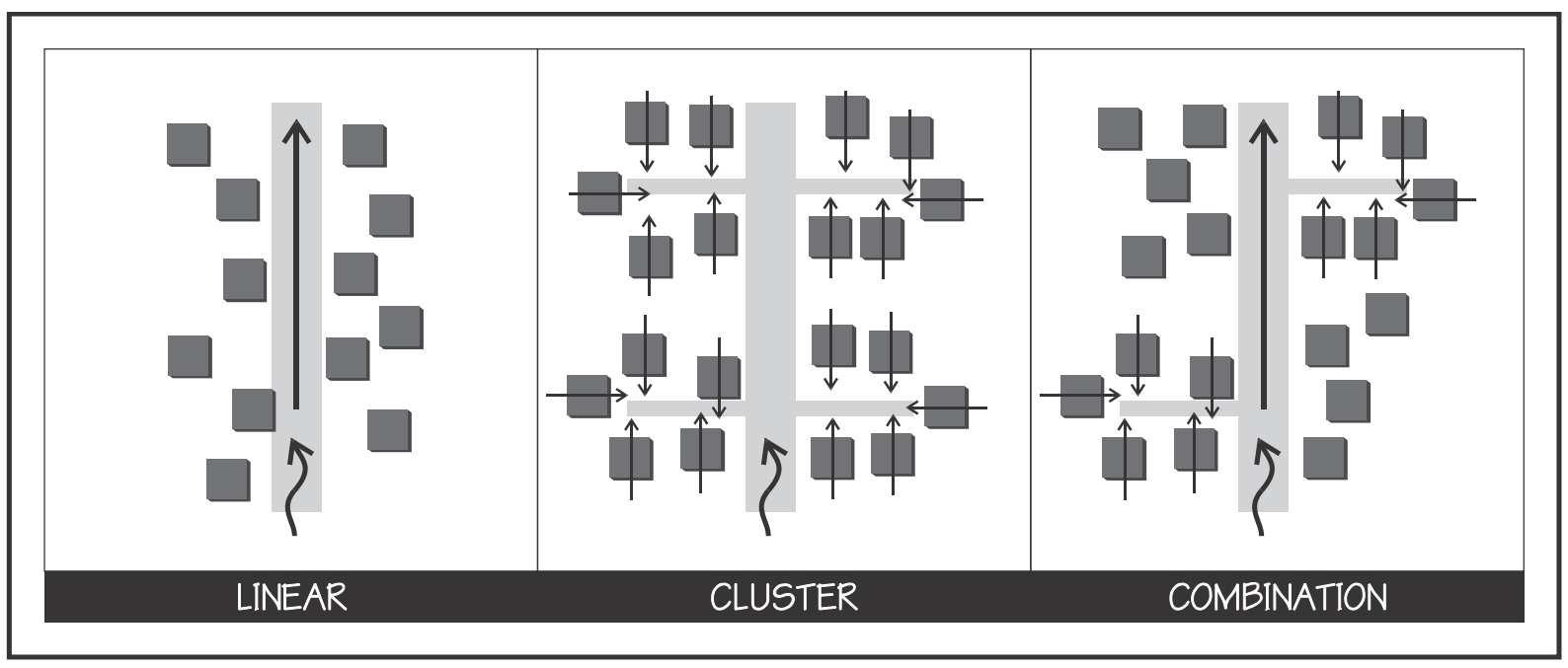

Gambar 2: Struktur Ruang Permukiman Sumber: Taylor, 1980

\subsection{Permukiman Tepian Air}

Pola permukiman di lingkungan perairan darat yang terpenting di Indonesia berada di tepi dan atau di atas perairan sungai. Sebagian permukiman ini sekaligus berada dalam lingkungan rawa dan perairan laut. Kondisi lingkungan perairan demikian mendorong pemukimnya membangun rumah panggung, bukan untuk menghindari pasang laut, melainkan menghindari luapan air sungai di musim hujan.

Pola permukiman tidak terbentuk dengan sendirinya tetapi melalui proses dan dipengaruhi beberapa faktor. Faktorfaktor pembentukan pola permukiman (Abdullah, 2000), yaitu;

a. Kondisi keamanan,

b. Saling - membutuhkan,

c. Hubungan kelompok,

d. Politik,

e. Agama,

f. Ideologi,

g. Budaya,

h. Bentuk fisik alam,

i. Ketersediaan Prasarana.

Berdasarkan hasil Pusat Penelitian dan
Pengembangan Pemukiman di tepi air Indonesia terdapat teori-teori (Suprijanto, 2002) antara lain:

a. Sejarah awal keberadaan lingkungan perumahan/pemukiman di kota tepi sungai dapat dibedakan atas 2 (dua) kronologis, yaitu:

- Perkembangan yang dimulai oleh kedatangan sekelompok etnis tertentu di suatu lokasi di tepi sungai, yang kemudian menetap dan berkembang secara turun temurun membentuk suatu komunitas serta cenderung bersifat sangat hemogen, tertutup dan mengembangkan tradisi dan nilai-nilai tertentu.

- Perkembangan sebagai daerah alternatif pemukiman, karena peningkatan arus urbanisasi, yang berakibat menjadi kawasan liar dan kumuh perkotaan.

b. Tahapan perkembangan kawasan pemukiman kota tepi sungai adalah:

- Tahap awal ditandai oleh dominasi pelayanan kawasan perairan sebagai sumber air untuk keperluan hidup masyarakat kota masih merupakan

Hal. 68 
suatu kelompok pemukiman di tepi sungai dan di atas air.

- Ketika kota membutuhkan komunikasi dengan lokasi lainnya (kepentingan perdagangan) maka kawasan perairan merupakan prasarana transportasi dan dapat diduga perkembangan fisik kota yang cenderung memanjang di tepi sungai (linier).

- Perkembangan selanjutnya ditandai dengan semakin kompleksnya kegiatan fungsional sehingga intensitas kegiatan di sekitar perairan makin tinggi.

c. Kawasan pemukiman diatas air cenderung rapat (kepadatan bangunan tinggi dan jarak antar bangunan rapat) dan kumuh (tidak teratur, kotor, dan lainlain).

d. Pola pemukiman di pengaruhi oleh keadaan topografi, dibedakan atas 3 (tiga), yaitu daerah perbukitan cenderung mengikuti kontur tanah, daerah relatif datar dan cenderung memiliki pola relatif teratur, yaitu pola grid atau linear dengan tata letak bangunan berada di kiri kanan jalan atau linier sejajar dengan (mengikuti) garis tepi sungai, daerah atas air pada umumnya cenderung memiliki pola cluster, yang tidak teratur dan organik. pada daerah-daerah yang telah ditata umumnya menggunakan pola grid atau linier sejajar garis badan sungai.

e. Orientasi bangunan semula umumnya menghadap perairan sesuai dengan orientasi kegiatan berbasiskan perairan. Perkembangan selanjutnya orientasi kegiatan ke darat semakin meningkat (bahkan lebih dominan), maka orientasi bangunan cenderung menghadap ke arah darat dan lebih mempertimbangkan aspek fungsional dan aksesblitas.

\section{Metodologi Penelitian}

Penelitian ini menggunakan metodologi kualitatif dengan pendekatan rasionalistik. Menurut Bogdan dan Tailor dalam Moeleong (2002) metodologi kualitatif sebagai prosedur penelitian yang menghasilkan data deskriptif berupa katakata tertulis atau lisan atau dari bentuk tindakan kebijakan. Menurut Muhajir (1996), pendekatan rasionalistik adalah pendekatan yang melihat kebenaran bukan semata-mata dari empiris tetapi juga argumentasi sebagai suatu bagian konstruksi berfikir. Penelitian ini menggunakan pendekatan rasionalistik karena menggunakan grand theory pada awal penelitian

Fokus dari penelitian ini adalah melakukan kajian terhadap karateristik pola permukimaan dengan melihat tahapan perkembangan, struktur pola permukiman, orientasi, kepadatan dan kualitas bangunan, serta topografi permukiman.

Penelitian ini berlokasi di desa Sepuk Laut, Tanjung Saleh dan Punggur Besar, Kecamatan Sungai Kakap, Kabupaten Kubu Raya, Propinsi Kalimantan Barat. Permukiman pada ketiga lokus tersebut memiliki karakteristik yang sama yaitu terletak di tepian air. Akses menuju lokasi hanya bisa dicapai melalui perjalanan sungai dan laut dari ibukota kecamatan. 


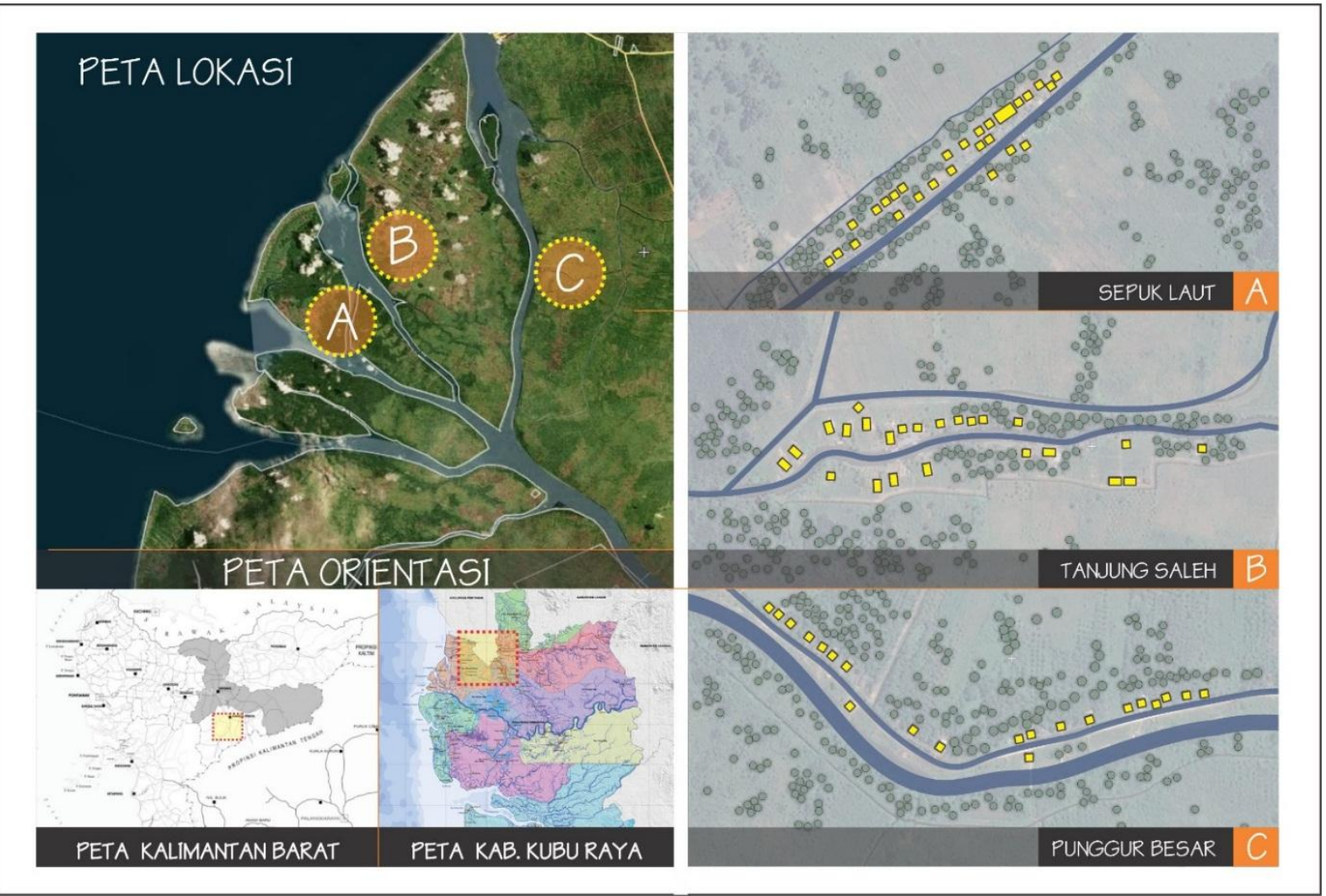

Gambar 3: Peta Lokasi Penelitian

Sumber: Penulis, 2014

\section{Pembahasan dan Hasil}

\subsection{Tahapan Perkembangan Kawasan}

Pertumbuhan dan perkembangan hunian di kawasan penelitian mengikuti pola aliran sungai. Pada kawasan penelitian belum terdapat jaringan jalan raya, sehingga semakin menguatkan fungsi aksesibilitas sungai. Sungai sebagai akses transportasi dan sumber air untuk keperluan hidup menjadi titik awal pertumbuhan kawasan. Area perkebunan dan pertanian yang terdapat di daratan memberi pengaruh terhadap pengelompokan permukiman kearah pinggiran sungai. Sehingga pola tata guna lahan secara tidak langsung terbentuk dengan sendirinya. Kawasan permukiman terletak di pinggiran sungai sedangkan pertanian dan perkebunan menjauhi sungai. 


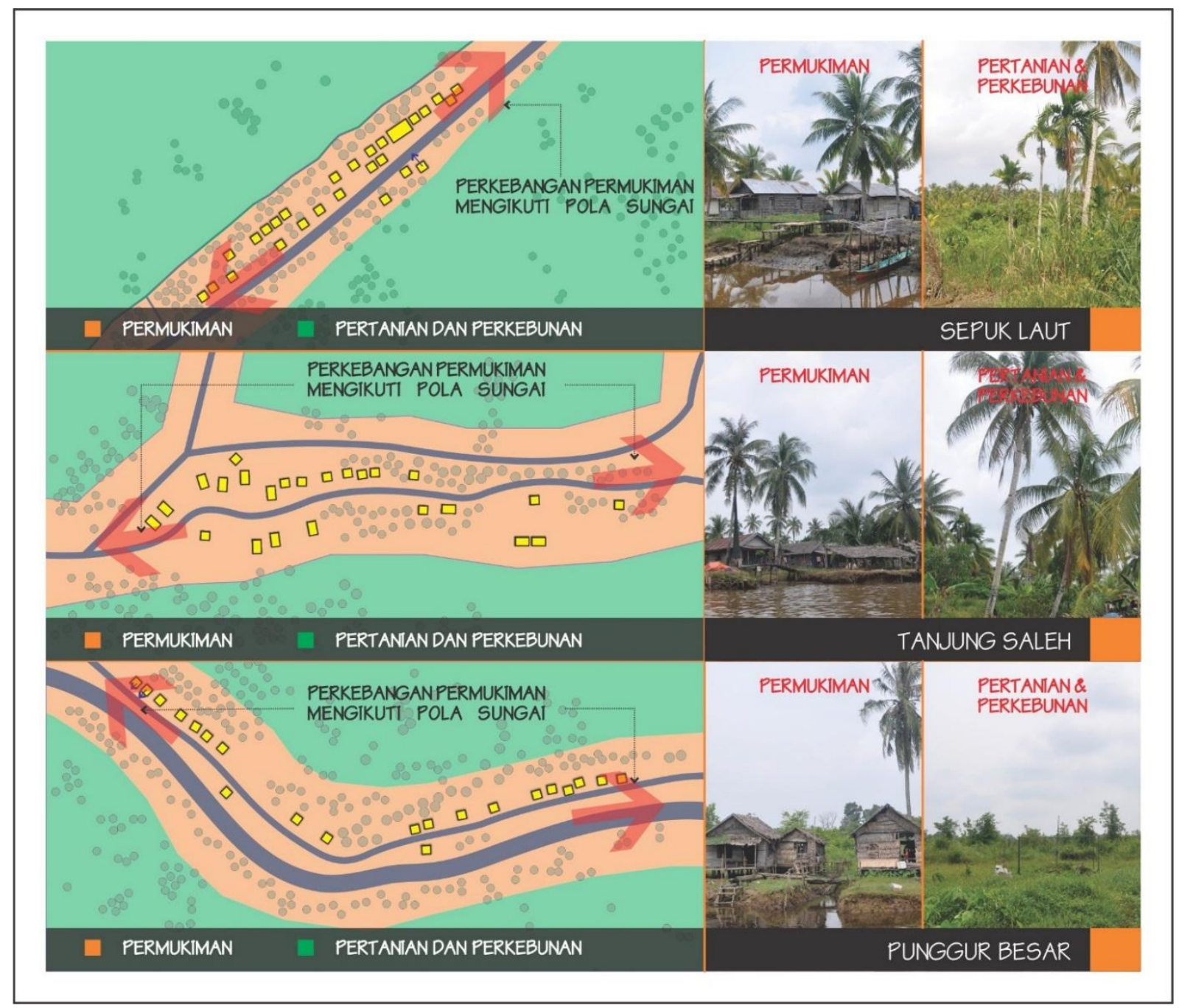

Gambar 4: Tahap Pengembangan Kawasan Sumber: Penulis, 2014

\subsection{Struktur Pola Permukiman}

Pola permukiman di lokasi penelitian ini membentuk pola linear. Sumbu linearnya berupa sungai dengan permukimannya berada di tepian sungai mengikuti pola sungai. Pola linear yang terbentuk membentuk tatanan permukiman yang sederhana dan teratur. Perkembangan permukiman juga mengikuti panjangnya aliran sungai tanpa ada ekspansi ke arah daratan yang lebih jauh. Sungai bagi masyarakat setempat mempunyai peran vital sebagai jalur transportasi menuju daerah lain sehingga mereka akan mendekatkan hunian dengan sungai. 


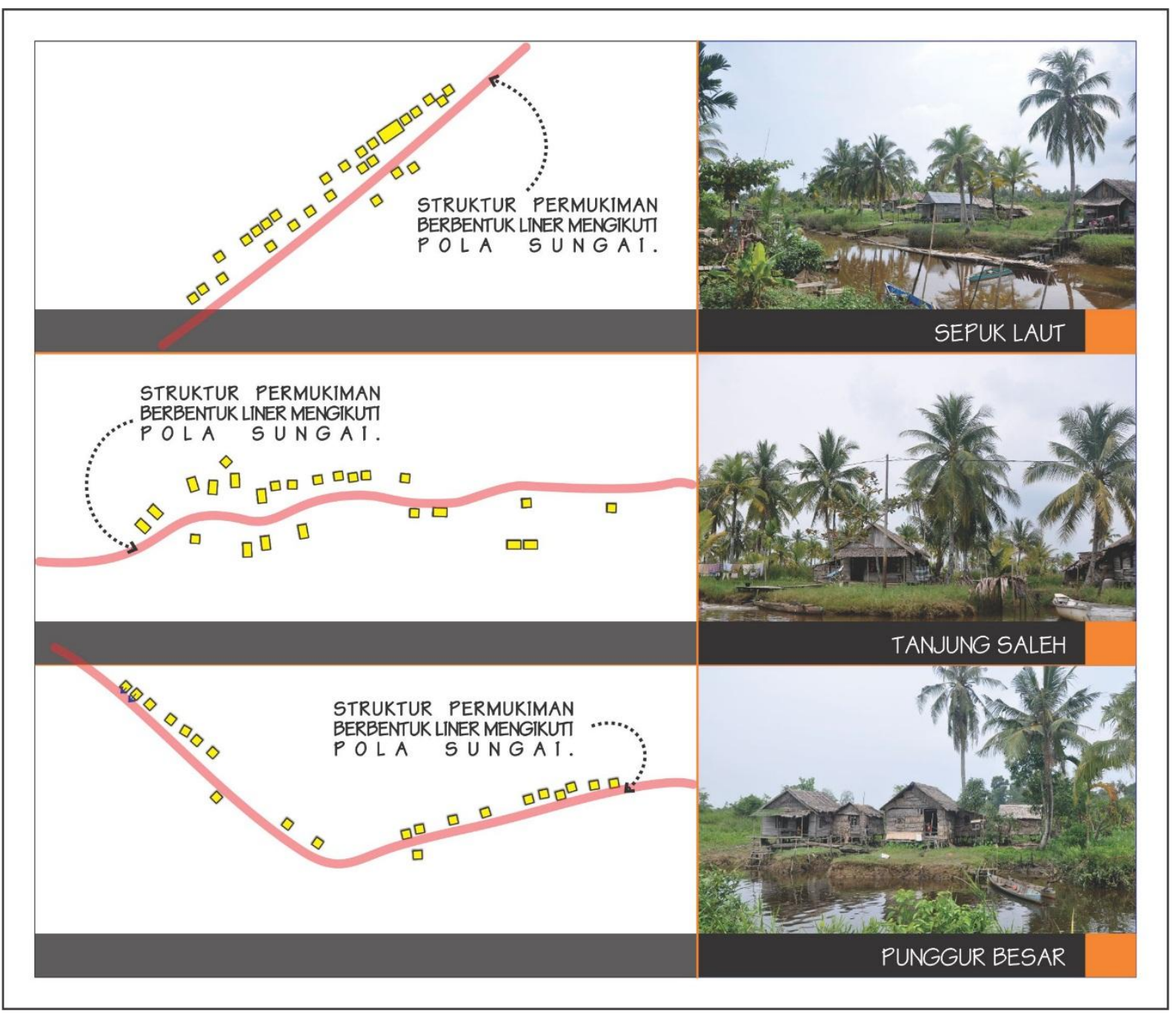

Gambar 5: Struktur Pola Permukiman Sumber: Penulis, 2014

\subsection{Orientasi}

Peran sungai yang vital bagi kehidupan masyarakat di lokasi penelitian berpengaruh terhadap orientasi bangunan. Setiap bangunan yang berada di tepian sungai akan meletakan entrance bangunan menghadap sungai. Orientasi bangunan terhadap sungai diperkuat dengan adanya jembatan (gertak) ke arah sungai tempat bersandar sampan mereka. Gertak juga difungsikan sebaai akses sirkulasi bangunan ke sungai atau antar sirkulasi antar rumah. 


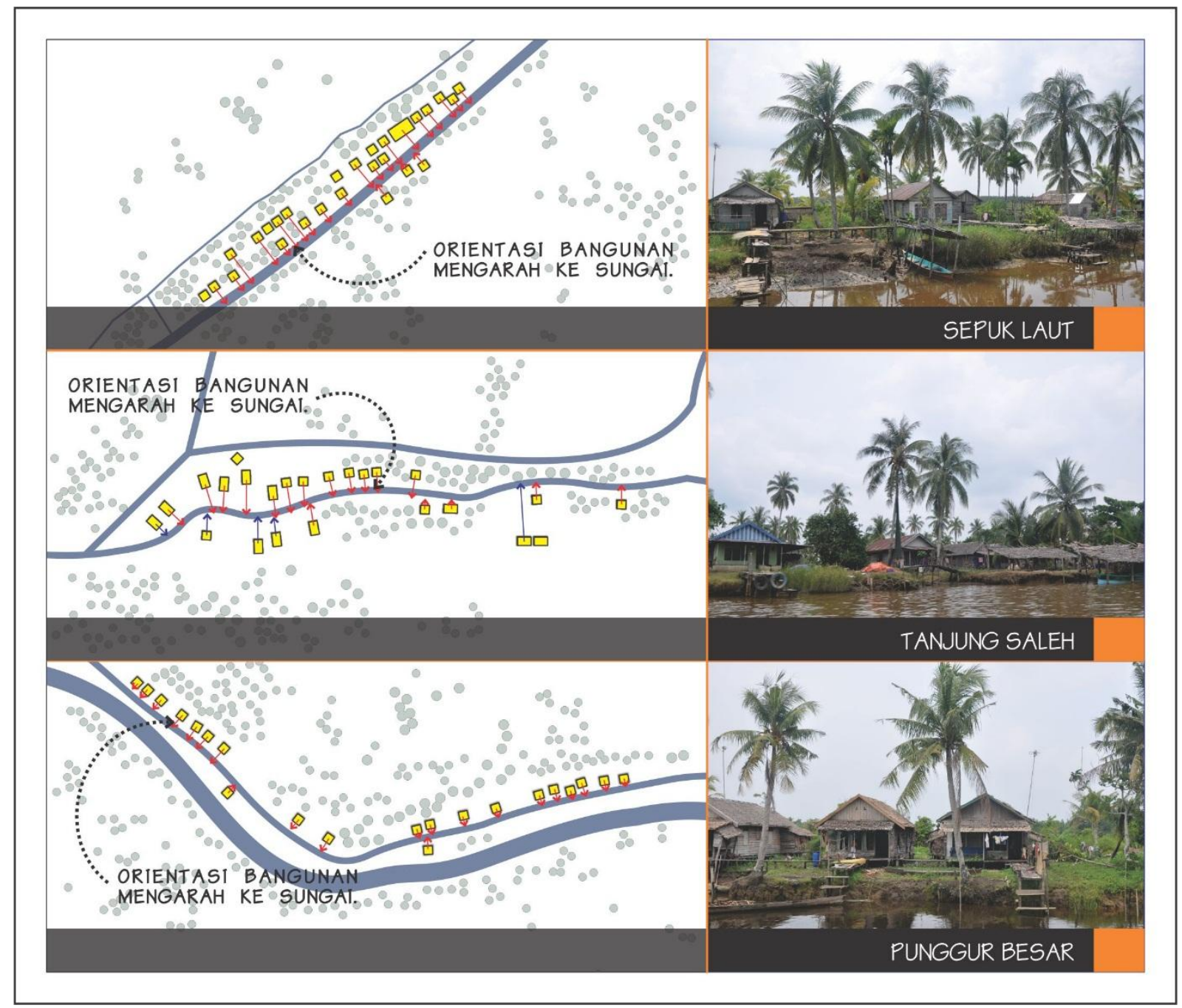

Gambar 6: Orientasi Bangunan Sumber: Penulis, 2014

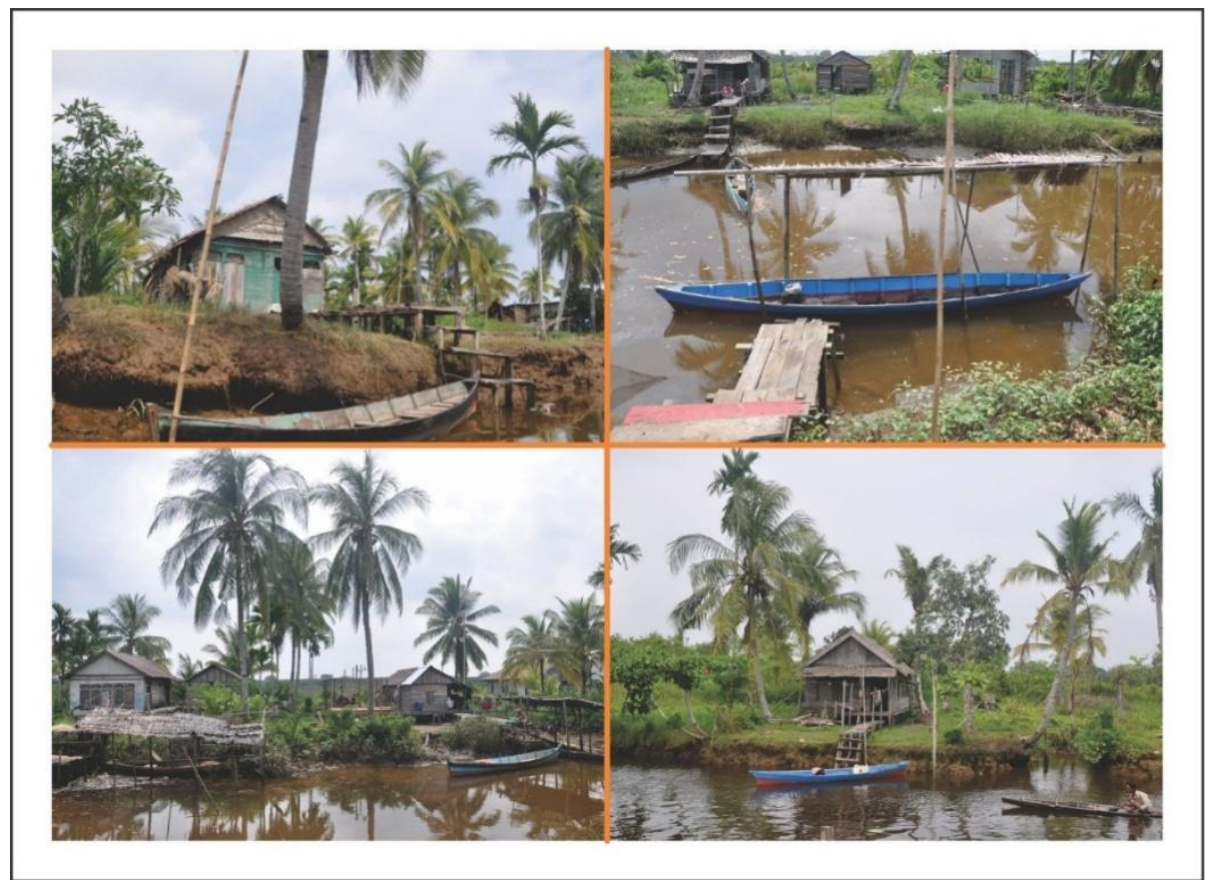

Gambar 7: Gertak pada Permukiman Sumber: Penulis, 2014 


\subsection{Kepadatan Bangunan dan Kualitas Bangunan}

Kepadatan bangunan di lokasi penelitian sangat rendah dengan jarak antar bangunan cukup jauh. Pengelompokan hunian hanya terdapat pada pinggiran sungai sedangkan yang mengarah pada daratan tidak terdapat hunian. Konstuksi bangunan menggunakan konstruksi kayu dengan bentuk bangunan berupa panggung.

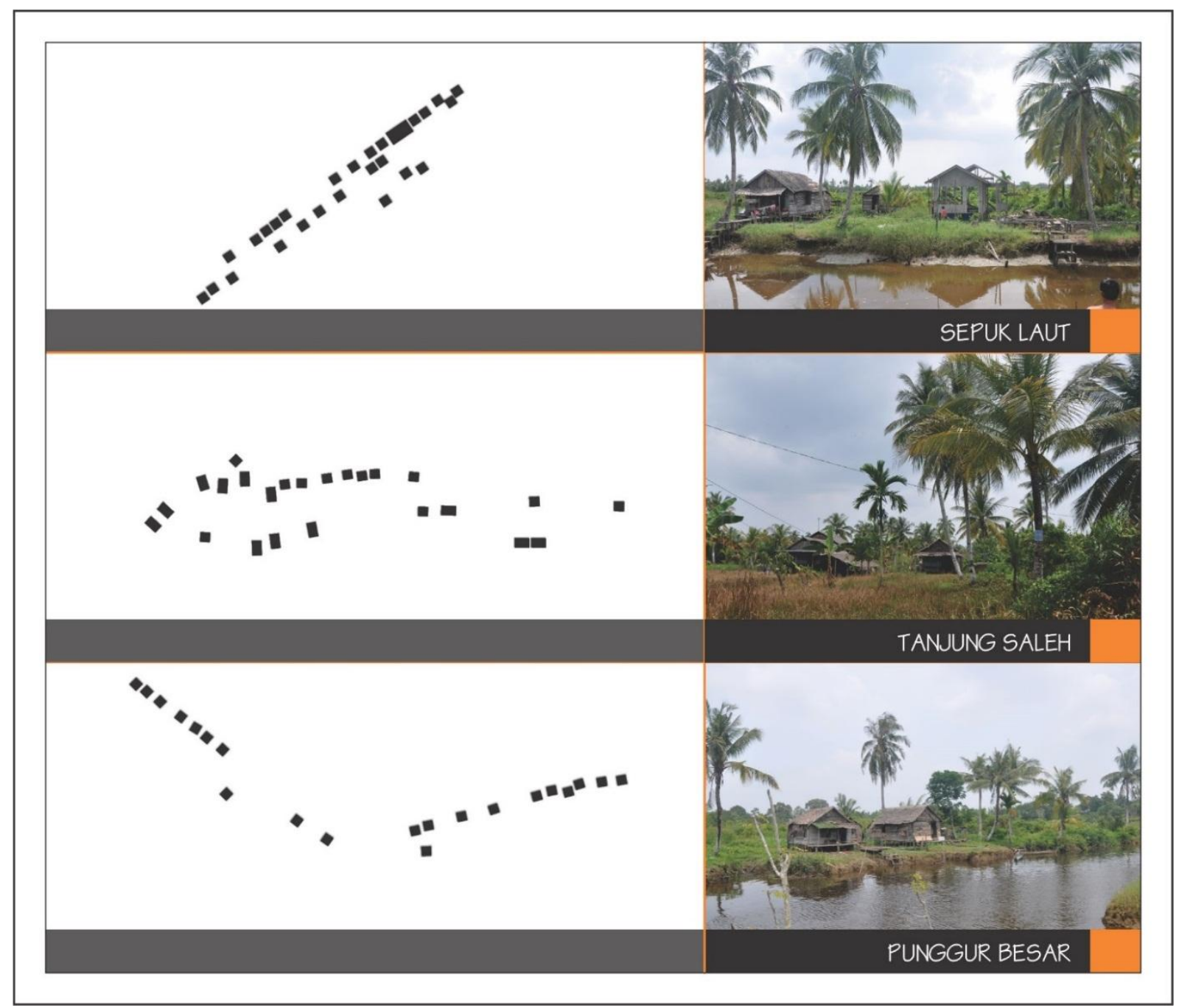

Gambar 8: Kepadatan Permukiman Sumber: Penulis, 2014

\subsection{Topografi}

Topografi di lokasi penelitian terdiri dari daratan dan perairan (sungai). Topografi di lokasi penelitian relatif datar sehingga pola permukiman yang terbentuk lebih teratur. keteraturan pola permukiman ini mengikuti pola aliran sungai yang linear. Dengan topografi yang relatif datar, mengakibatkan ada beberapa daerah yang mengalami pasang-surut laut. Untuk mengantisipasi pasang-surut laut hunian dibuat dengan konsep bangunan panggung dengan jalur penghubung antar bangunan berupa jembatan (gertak kayu). Sebagai penghubung hunian yang berseberangan dibuat jembatan penghubung dengan konstruksi kayu. 


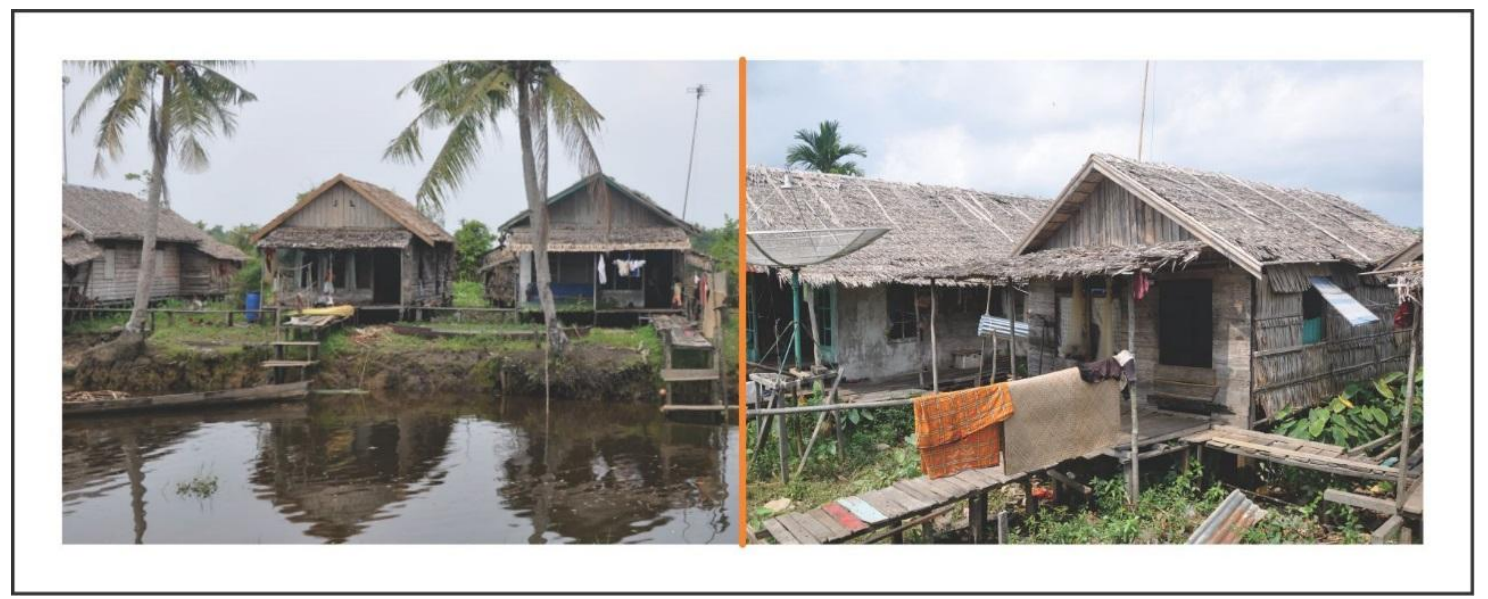

Gambar 9: Gertak Sebagai Akses Antar Bangunan Sumber: Penulis, 2014

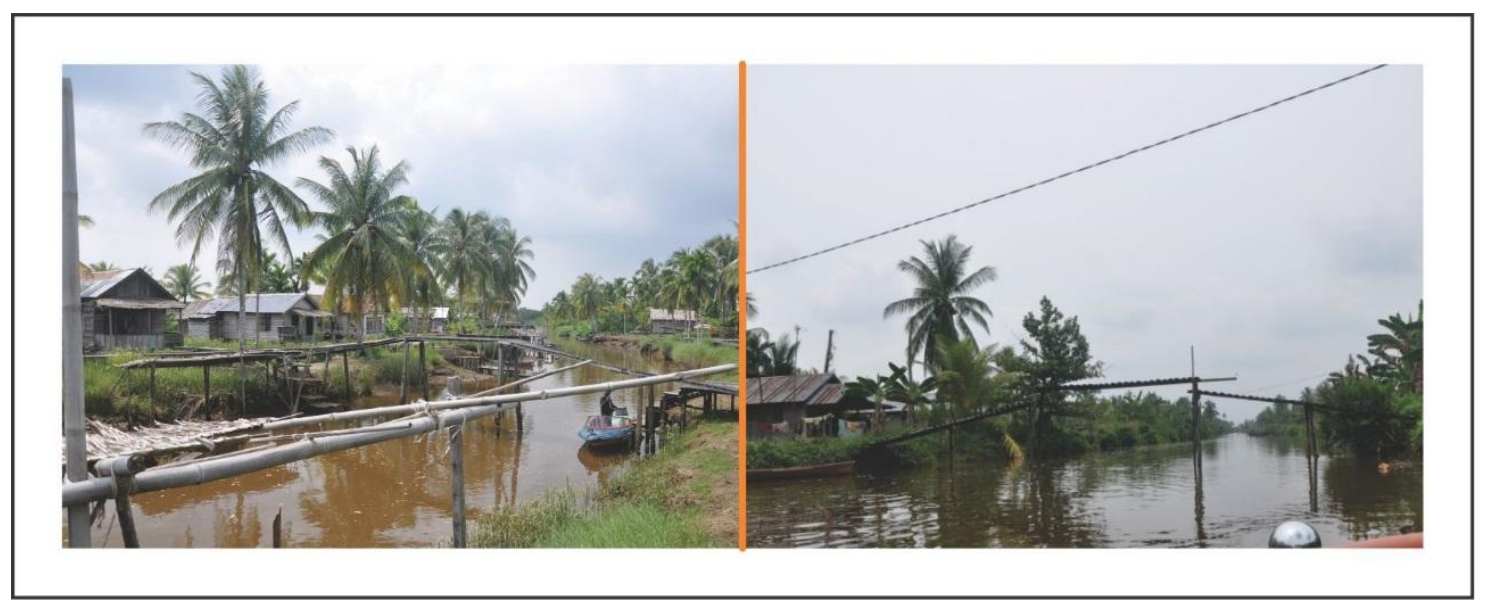

Gambar 10: Jembatan Penghubung untuk Akses Bangunan yang Dipisahkan oleh Sungai Sumber: Penulis, 2014

\section{Kesimpulan}

Berdasarkan hasil pembahasan terhadap pola permukiman tepian air di desa Sepuk Laut, Punggur Besar dan Tanjung Saleh kecamatan Sungai Kakap Kabupaten Kubu Raya dapat disimpulkan sebagai berikut:

a. Tahapan perkembangan kawasan penelitian berawal dari pinggiran sungai atau tepian air dan perkembangan berikutnya mengikuti sungai sebagai akses transportasi.

b. Struktur pola permukiman kawasan berbentuk linear mengikuti pola sungai yang memanjang.

c. Orientasi bangunan mengarah ke sungai dengan fasade bagian depan terdapat gertak untuk meletakan sampan.

d. Kepadatan bangunan pada kawasan penelitian rendah dengan jarak bangunan yang cukup jauh. Antar bangunan saling terhubung melalui jembatan (gertak).

e. Topografi di kawasan penelitian relatif datar sehingga pasang surut air laut berdampak terhadap terhadap bentuk rumah yaitu rumah panggung.

\section{Daftar Pustaka}

Abdullah. 2000. Upaya Meningkatkan Income Penduduk Kawasan Penyangga Kota Melalui Penataan Prasarana Permukiman. laporan penelitian. Lemlit Universitas Tadulako. Palu

Bertrand, Alvin L. 1972. Seventy Years or Rural Sociology in The United States.Essay Press. New York

Bintarto, R. !983. Interaksi Desa Kota dan Permasalahannya. Ghalia. Jakarta 
Depdikbud, 1988. Kamus Besar Bahasa Indonesia. Balai Pustaka. Jakarta

Moeleong, Lexy. 2002. Metode Penelitian Kualitatif. Remaja Rosdakarya. Bandung

Muhajir, Noeng. 1996. Metodologi Penelitian Kualitatif. Rake Sarasin. Yogyakarta

Rapoport, Amos (1989). Dwelling Settlement and Tradition. Prentice Hall Inc. London

Snyder, J.C; Catanese A.J. 1985. Pengantar Arsitektur. Erlangga. Jakarta.

Suprijanto, I. 2001.Model Pengembangan Kawasan Kota Tepi Air. Makalah pada KOLOKIUM Hasil Litbang PUSKIM 2002. Puslitbang Permukiman. Balitbang Departemen Kimpraswil

Taylor, Lee. 1980. Urbanized Society. Goodyear Puiblishing Company Inc. Santa Monica, California.

Turner, F, C. 1976. Housing Policy by People: Towards Autonomy in Building Environment. Marion Boyars. London 